\title{
DZIAŁANIA REKLAMOWE - OD KOMERCJI DO KAMPANII SPOŁECZNYCH
}

\author{
Iwona Herbuś \\ Politechnika Częstochowska \\ Wydział Zarządzania
}

\begin{abstract}
Streszczenie: Celem niniejszego artykułu jest zaprezentowanie reklamy społecznej i kampanii społecznych jako ważnych elementów funkcjonowania współczesnego społeczeństwa. W opracowaniu zostało również przedstawione porównanie reklamy komercyjnej i reklamy społecznej. Mimo odmiennych zadań do spełnienia posiadają wiele cech wspólnych. Obie są złożonym procesem wymagającym dokładnego przygotowania. Znaczący element każdej kampanii społecznej stanowią jej odbiorcy, którzy są zazwyczaj dużo obszerniejszą grupą niż w reklamie komercyjnej. Na końcu artykułu przedstawione zostały przykłady kampanii społecznych realizowanych w Polsce i na świecie dotyczące środowiska naturalnego i praw zwierząt.
\end{abstract}

Słowa kluczowe: reklama, reklama społeczna, kampania społeczna

DOI: $10.17512 /$ znpcz.2016.2.08

\section{Wprowadzenie}

W czasach postępującej degradacji środowiska naturalnego oraz wzrastających problemów społecznych bardzo ważną rolę odgrywają kampanie społeczne, a w konsekwencji reklamy społeczne. Ich zadaniem jest zakomunikowanie oraz dostarczenie odbiorcom informacji na temat istotnego problemu społecznego lub środowiskowego. Ponadto reklamy społeczne powinny propagować pozytywne postawy oraz negować niewłaściwe zachowania. Wiele podmiotów chętnie angażuje się we współpracę i pomoc przy tworzeniu lub realizowaniu kampanii społecznych, co również wpływa pozytywnie na ich wizerunek i relacje z otoczeniem. Liczne reklamy oraz kampanie społeczne stały się obecnie nieodłącznym elementem mediów i funkcjonowania organizacji charytatywnych.

\section{Reklama i jej znaczenie dla współczesnych przedsiębiorstw}

Reklama to jeden $z$ najważniejszych elementów komunikacji organizacji dochodowych z interesariuszami. Obecna rzeczywistość często wymusza na przedsiębiorstwach ciągłe rozwijanie i unowocześnianie działań promocyjnych. Znaczenie promocji uzależnione jest od wielu czynników, wśród których wymienia się (https://www.parp.gov.pl/files/74/517/20358.pdf):

- poziom konkurencyjności na określonym rynku,

- charakterystykę rynku, na którym funkcjonuje przedsiębiorstwo, 
- plany organizacji w stosunku do danego rynku,

- jakość oferowanych towarów,

- zróżnicowanie produktu,

- nastawienie odbiorców do danego przedsiębiorstwa.

Wymienione czynniki silnie wpływają na działania promocyjne prowadzone w różnych organizacjach. Promocja mix obejmuje pięć elementów: reklamę, public relations (PR), sprzedaż osobistą, marketing bezpośredni i promocję sprzedaży (Pabian 2008, s. 29-31).

Reklama jest to płatna forma bezosobowego przekazu, docierająca do anonimowego, masowego odbiorcy, której zadaniem jest zachęcenie go do kupna lub używania określonych produktów lub usług (Sławińska (red.) 2008, s. 149). Reklama na przestrzeni wielu lat znacznie się zmieniła. Jednak nadal spełnia następujące funkcje (Kotler 2005, s. 601):

- informacyjną - ma za zadanie przekazanie informacji o nowych produktach lub o wprowadzeniu nowych cech do znanego już produktu;

- nakłaniającą - jej celem jest wywołanie sympatii do danego produktu i przekonanie odbiorcy do jego nabycia;

- przypominającą - ma przypominać o danych towarach w celu powtórnego zakupu;

- wzmacniającą - ma przekonać konsumentów, którzy zakupili dany produkt, że podjęli właściwą decyzję.

W przedsiębiorstwach reklamy często dzielone są na trzy grupy. Pierwszą $\mathrm{z}$ nich stanowi reklamowa masowa, która adresowana jest do największej grupy odbiorców. Ponadto wykorzystuje środki masowego przekazu, tj. radio, telewizję czy prasę. Drugi rodzaj to reklama półmasowa, która skierowana jest do wybranych grup odbiorców na przykład do fachowców. Można się z nią spotkać także w sklepach lub na targach wystawienniczych. Trzeci, ostatni rodzaj to reklama indywidualna, która adresowana jest do szczegółowo określonych odbiorców. Jako przykład może służyć tutaj reklama pocztowa lub internetowa (Kaczmarczyk, Pałgan 2005, s. 278-282).

Przedsiębiorstwa, tworząc reklamy, często korzystają z koncepcji 6M (Budzyński 2007, s. 32):

- $1 \mathrm{M}$ - mission - określenie kluczowych celów reklamy,

- 2M-market - wybór adresatów reklamy,

- 3M-money - ustalenie budżetu reklamy,

- 4M-message - dobór treści reklamowych,

- 5M-media-określenie mediów reklamowych,

- 6M-measurement - kontrolowanie skuteczności reklamy.

Koncepcja 6M pozwala na szczegółowe opracowanie, wdrażanie oraz kontrolowanie działań reklamowych w organizacji. Realizując określone działania reklamowe, organizacje powinny sprawdzać również opinię publiczną na ich temat. W tym obszarze wyróżnić można siedem wymiarów postaw wobec reklamy (Wiktor 2006, s. 284): 
- wymiar informacyjny - reklama stanowi źródło informacji o danej firmie i jej ofercie;

- wymiar identyfikacji społecznej - przekaz reklamowy dostarcza wiadomości na temat stylu życia, mody oraz ról społecznych;

- wymiar satysfakcji - reklama dostarcza pewnego rodzaju rozrywki oraz powinna być przyjemna dla odbiorcy;

- wymiar materializmu - reklama propaguje konsumpcyjny styl życia;

- wymiar negatywnych wartości - reklama wywiera negatywny wpływ na podstawowe wartości społeczne i odbiorców przekazu reklamowego;

- wymiar dezinformacji - reklama zniekształca informacje oraz wprowadza w błąd konsumenta.

Powyższe stwierdzenia pokazują, że reklama jest złożonym narzędziem i ma silny wpływ na odbiorcę, mimo że często kojarzona jest z jednostronnym przekazem służącym tylko do rozpromowania określonego produktu lub wybranej usługi. Należy jednak pamiętać, że forma i przekaz reklamy silnie oddziałują na odbiorców. Nie tylko na grupę docelową, ale również na wszystkich konsumentów, którzy mogą spotkać się z reklamą na przykład w mediach.

Podobna sytuacja dotyczy reklamy społecznej, która również jest długotrwałym i złożonym narzędziem komunikacji z otoczeniem, ale spełnia dużą obszerniejszą i ważniejszą rolę niż reklama komercyjna.

\section{Reklama społeczna jako nieodłączny element kampanii społecznej}

Postępującemu rozwojowi gospodarczemu oraz technologicznemu nierozerwalnie towarzyszy wzrost problemów cywilizacyjnych. Sytuacja ta doprowadziła do potrzeby poruszania i omawiania tych problemów na większych forach. W tym obszarze niezwykle pomocna jest reklama społeczna.

Reklama społeczna definiowana jest przez cel, jaki sobie stawia. Oznacza to, że jej zadaniem jest nakłanianie do zachowań potrzebnych i korzystnych z punktu widzenia społeczeństwa oraz negowanie działań niewłaściwych i negatywnych postaw. Bardzo ważne również jest zainteresowanie społeczeństwa daną problematyką (Limański, Drabik 2007, s. 211-212).

Przygotowując reklamę społeczną, należy pamiętać o jej specyficznej charakterystyce, która w zdecydowanym stopniu różni się od reklamy komercyjnej. Różnice zostały przedstawione w Tabeli 1 .

Różnice między reklamą komercyjną a reklamą społeczną są znaczące. Bardzo istotny jest przekaz i forma reklamy społecznej. Musi być on zapamiętywalny i wywoływać silne emocje u odbiorcy. Reklamy społeczne często kojarzone są $\mathrm{z}$ nieprzyjemną, a czasem nawet drastyczną formą. Jednak w ostatnich latach coraz popularniejsze stają się również reklamy społeczne posiadające przyjemny przekaz. W reklamach społecznych bardzo istotne również jest to, że zazwyczaj grupy docelowe są dużo obszerniejsze niż w reklamach komercyjnych, ponieważ często są skierowane do całego społeczeństwa, a nie tylko do określonych jednostek lub podmiotów. 
Tabela 1. Porównanie reklamy komercyjnej i społecznej

\begin{tabular}{|c|c|c|}
\hline Płaszczyzna & Reklama społeczna & Reklama komercyjna \\
\hline Cele & $\begin{array}{l}\text { Uwrażliwienie konkretnych grup } \\
\text { lub całego społeczeństwa, kształ- } \\
\text { towanie dobrych postaw } \\
\text { i negowanie niewłaściwych zacho- } \\
\text { wań }\end{array}$ & $\begin{array}{l}\text { Sprzedaż produktu, poprawienie } \\
\text { rozpoznawalności marki } \\
\text { i przedsiębiorstwa, zdobycie lub } \\
\text { powiększenie grupy klientów }\end{array}$ \\
\hline Intencje nadawcy & $\begin{array}{c}\text { Chęć pomocy innym - duże zaufa- } \\
\text { nie do nadawcy }\end{array}$ & $\begin{array}{l}\text { Chęć zysku - mocno ograniczo- } \\
\text { ne zaufanie do nabywcy lub jego } \\
\text { całkowity brak }\end{array}$ \\
\hline Korzyści odbiorcy & $\begin{array}{c}\text { Czasem trudne do wyobrażenia } \\
\text { wiążące się z odroczoną perspek- } \\
\text { tywą lub nieprzynoszące korzyści } \\
\text { bezpośrednich określonym jednost- } \\
\text { kom }\end{array}$ & $\begin{array}{l}\text { Odczuwalne natychmiast lub } \\
\text { w krótkim czasie, dotyczące } \\
\text { konkretnych ściśle określonych } \\
\text { jednostek }\end{array}$ \\
\hline $\begin{array}{l}\text { Poziom zmiany } \\
\text { postawy odbiorcy }\end{array}$ & $\begin{array}{l}\text { Często znaczny i głęboki, wiążący } \\
\text { się ze zmianą postaw lub zrezy- } \\
\text { gnowaniem z określonych działań, } \\
\text { które mogą być np. niebezpieczne }\end{array}$ & $\begin{array}{l}\text { Mało znaczący i płytki, wiążący } \\
\text { się ze zmianą zachowań konsu- } \\
\text { menckich, np. zmiana marki } \\
\text { wybranego produktu }\end{array}$ \\
\hline Przekaz & $\begin{array}{l}\text { Czasem nieprzyjemny, działający } \\
\text { silenie na psychikę odbiorców }\end{array}$ & $\begin{array}{c}\text { Zazwyczaj bardzo przyjemny } \\
\text { wywołujący pozytywne emocje }\end{array}$ \\
\hline Budżet & $\begin{array}{c}\text { Zazwyczaj niewielki } \\
\text { (w zależności od kampanii spo- } \\
\text { łecznej) }\end{array}$ & $\begin{array}{l}\text { Zwykle wysoki lub bardzo } \\
\text { wysoki } \\
\text { (w zależności od rodzaju } \\
\text { reklamy) }\end{array}$ \\
\hline
\end{tabular}

Źródło: Opracowanie własne na podstawie: (Maison, Wasilewski 2002, s. 10)

Reklama społeczna, podobnie jak reklama komercyjna, oddziałuje na odbiorcę w trzech obszarach (Kozłowska 2012, s. 102-103):

- obszar poznawczy - uświadomienie o istnieniu danego problemu oraz informowanie o nim,

- obszar emocjonalny - odwoływanie się do pozytywnych i negatywnych emocji,

- obszar behawioralny - zachwalanie i przekonywanie do zachowań prospołecznych oraz negowanie i namawianie do zaniechania postaw szkodliwych lub niewłaściwych.

Reklama społeczna zazwyczaj jest elementem kampanii społecznej. Kampania społeczna to zbiór określonych działań zaplanowanych w konkretnym czasie, skierowanych do określonej grupy odbiorców. Jej celem jest doprowadzenie do zwiększenia wiedzy na dany temat, zmiany poglądów lub wywołania konkretnego zachowania dotyczącego określonego problemu społecznego. Najważniejszym zadaniem kampanii społecznych jest osiąganie wspólnego dobra (Prochenko 2010). Kampania społeczna jest także formą działań społecznie zaangażowanych organizacji, realizowana jest najczęściej przy współpracy różnych podmiotów (Gołaszewska-Kaczan 2009, s. 108-109).

Projektowanie kampanii społecznej składa się z następujących etapów (Tarczydło 2013, s. 228): 
1. Pomysł i idea.

2. Określenie potencjalnych sojuszników (interesariuszy).

3. Przekonanie partnerów do współpracy.

4. Opracowanie konkretnego przesłania.

5. Doprecyzowanie celów kampanii.

6. Przedstawienie konkretnych faktów dotyczących problemu.

7. Określenie zakresu działań.

8. Wdrożenie oraz kontrola i pomiar rezultatów.

Opracowanie kampanii społecznej to złożony i długotrwały proces, często uzależniony od określonego zdarzenia lub czasu. W związku z tym można zauważyć powtarzalność niektórych kampanii i reklam społecznych, sięgających do zbliżonych problemów i wykorzystujących podobne narzędzia przekazu.

\section{Przykłady kampanii społecznych}

W niniejszym rozdziale przestawiono przykładowe kampanie społeczne realizowane w Polsce i na świecie. Ich charakterystyka została zawarta w Tabeli 2.

Tabela 2. Przykłady kampanii spolecznych

\begin{tabular}{|c|c|}
\hline Nazwa kampanii & Opis \\
\hline $\begin{array}{l}\text { „Pandy opanowały } \\
\text { Hongkong” } \\
\text { (Czas: } 06.2014 \\
\text { Miejsce: Hongkong) }\end{array}$ & $\begin{array}{l}1600 \text { pand zrobionych z papieru zostało umieszczonych w Hongkongu. } \\
\text { Wcześniej pandy odwiedziły Berlin i Paryż. Ilość nie była przypadkowa, } \\
\text { ponieważ liczba osobników żyjących na wolności najprawdopodobniej nie } \\
\text { przekracza } 1600 \text {. Celem kampanii było zwrócenie uwagi na pandy jako } \\
\text { zagrożony gatunek oraz zebranie funduszy i wspieranie działań prowadzo- } \\
\text { nych przez WWF (Word Wildlife Fund) na ich rzecz. } \\
\end{array}$ \\
\hline $\begin{array}{l}\text { „Miś w Amsterdamie” } \\
\text { (Czas: } \\
07.10 .2010 \text { - 10.10.2010 } \\
\text { Miejsce: Amsterdam) }\end{array}$ & $\begin{array}{l}\text { Pływająca makieta niedźwiedzia polarnego przepłynęła miejskimi kanałami } \\
\text { w mieście na niewielkiej lodowej krze. Celem akcji było zwrócenie uwagi na } \\
\text { postępujące zmiany klimatu i ich konsekwencje. }\end{array}$ \\
\hline $\begin{array}{l}\text { "Co minutę zegar zabija } \\
\text { zwierze" } \\
\text { (Czas: 06.2011 } \\
\text { Miejsce: Niemcy) }\end{array}$ & $\begin{array}{l}\text { Uwięzione między wskazówkami ogromnego zegara niedźwiedź brunatny, } \\
\text { foka szara i goryle w drastyczny sposób pokazują, że czas płynie nieubłaganie } \\
\text { dla zagrożonych gatunków. Celem kampanii było zwrócenie uwagi na problem } \\
\text { wymierania gatunków, który jest następstwem zmian klimatycznych. }\end{array}$ \\
\hline $\begin{array}{l}\text { „Wspaniały zwierzak } \\
\text { chce kogoś poznać" } \\
\text { (Czas: } \\
\text { 19.02.2014 - 19.03.2014 } \\
\text { Miejsce: } \\
\text { Stany Zjednoczone) }\end{array}$ & $\begin{array}{l}\text { Szczę́liwe psy i koty pukają od wewnątrz w szybę telewizora. Ich zadaniem } \\
\text { jest zachęcenie ludzi do adopcji zwierząt. Organizacja The Shelter Pet Project } \\
\text { pomaga bezdomnym zwierzętom i chce dotrzeć do odbiorcy w sposób nie } \\
\text { drastyczny, lecz przyjemny, pokazujący, że zaadoptowany pies lub kot dostar- } \\
\text { cza w domu wiele szczęścia i radości. W ramach akcji zaprezentowano wiele } \\
\text { zwierząt, które za pośrednictwem The Shelter Pet Project znalazły dom. }\end{array}$ \\
\hline $\begin{array}{l}\text { „Pies, który przetrwał” } \\
\text { (Czas: 09.2015 } \\
\text { Miejsce: } \\
\text { Wielka Brytania) }\end{array}$ & $\begin{array}{c}\text { Spot przedstawia psa „śpiewającego” znany utwór „I will survive”, opowia- } \\
\text { da o jego długiej walce o przeżycie i znalezienie nowego domu. Spot został } \\
\text { zrealizowany na zlecenie organizacji Blue Cross, która pomaga porzuconym } \\
\text { zwierzętom. W reklamie społecznej poznajemy psa Baxtera, który również } \\
\text { znalazł się na ulicy, ale po wielu przeciwnościach udało mu się odnaleźć } \\
\text { nowy dom. Wykorzystany w spocie utwór muzyczny ma przybliżyć odbior- } \\
\text { com problem bezdomności zwierząt, ponieważ jego słowa odwzorowują } \\
\text { przeżycia głównego bohatera. Ma również zwrócić uwagę odbiorcy i zainte- } \\
\text { resować go poruszaną problematyką. }\end{array}$ \\
\hline
\end{tabular}




\begin{tabular}{|c|c|}
\hline $\begin{array}{l}\text { „Wilk i ryś patrzą } \\
\text { w oczy” } \\
\text { (Czas: } 04.2015 \\
\text { Miejsce: Polska) }\end{array}$ & $\begin{array}{l}\text { Wilk, ryś, foka i niedźwiedź spoglądają prosto w oczy oglądających plakaty. } \\
\text { Kampania outdoorowa została wsparta również spotem telewizyjnym. Celem } \\
\text { akcji było zwrócenie uwagi na rzadkie i zagrożone gatunki w Polsce oraz } \\
\text { zachęcenie do przekazania } 1 \% \text { podatku na WWF Polska w celu wsparcia } \\
\text { działań na rzecz ochrony tych zwierząt. Hasło przewodnie kampanii brzmia- } \\
\text { ło następująco: „Spójrz mi w oczy. Bądź moim głosem. Pomóż”. } \\
\end{array}$ \\
\hline $\begin{array}{c}\text { „1000 lodowych ludzi } \\
\text { w Berlinie” } \\
\text { (Czas: } 12.2010 \\
\text { Miejsce: Berlin) }\end{array}$ & $\begin{array}{c}\text { Jedna z najbardziej widowiskowych kampanii WWF adresowana zarówno } \\
\text { do niemieckich przechodniów, jak i polityków. Na jednym z berlińskich } \\
\text { placów ustawiono } 1000 \text { lodowych rzeźb, przedstawiających ludzi siedzących } \\
\text { na swoich rękach, co miało symbolizować bierność i brak działania na rzecz } \\
\text { powstrzymania zmian klimatycznych. Rzędy białych sylwetek przypominały } \\
\text { z daleka miniaturę społeczeństwa. Celem kampanii było przedstawienie } \\
\text { „zagłady” lodowych postaci, będącej metaforą ignorowania problemu top- } \\
\text { niejących lodowców w Arktyce. }\end{array}$ \\
\hline $\begin{array}{c}\text { „Przyjaciół się nie wy- } \\
\text { rzuca” } \\
\text { (Czas: 02.2011 } \\
\text { Miejsce: Łódź) }\end{array}$ & $\begin{array}{l}\text { W mieście Łódź została zorganizowana kampania przeciwdziałająca porzu- } \\
\text { caniu zwierząt. Z samochodów do przewożenia odpadów spoglądają koty } \\
\text { i psy, a na każdym zdjęciu znajduje się hasło: „Przyjaciół się nie wyrzuca”. } \\
\text { Jednym z organizatorów kampanii była Fundacja Niechciane i Zapomniane } \\
\text { - SOS dla Zwierząt. Celem akcji było podkreślenie, że zwierzęta to żywe } \\
\text { istoty, które czują i bardzo mocno przywiązują się do swoich opiekunów, } \\
\text { a nie przedmioty, które - kiedy się znudzą lub przestają być potrzebne - } \\
\text { można wyrzucić. Ponadto organizatorzy akcji chcieli zaznaczyć, że adopcja } \\
\text { zwierzęcia powinna być oparta na odpowiedzialnej i przemyślanej decyzji. }\end{array}$ \\
\hline
\end{tabular}

Źródło: http://www.kampaniespoleczne.pl/; http://www.wwf.pl/; http://przerwanareklame.pl/

Przedstawione przykłady kampanii społecznych dotyczą ekologii i ochrony praw zwierząt, problemów nie zawsze uregulowanych prawnie, wymagających jednak wrażliwości i odpowiedzialności społecznej. Materiały graficzne bądź filmy wideo do wymienionych $\mathrm{w}$ tabeli akcji znajdują się na stronie internetowej: www.kampaniespołeczne.pl.

Wymienione wyżej kampanie społeczne - mimo wspólnego celu, jakim jest zwrócenie uwagi na poważne problemy - są bardzo zróżnicowane. Działania realizowane w ramach każdej akcji mają odmienny charakter. Pokazuje to, że reklamy społeczne nadal jeszcze przybierają drastyczną formę i pokazują negatywne skutki nieprzywiązywania wagi do danej problematyki. Jednak coraz częściej mają również przyjemny charakter, który ma wywołać w odbiorcy pozytywne emocje oraz zaprezentować korzyści płynące z rozwiązania lub przeciwdziałania określonym problemom.

\section{Podsumowanie}

Reklama to działanie promocyjne, z którym spotykamy się na co dzień. Może przybierać ona bardzo różną formę i dotyczyć ogromnej ilości towarów. Reklama spełnia również określone funkcje, a jej głównym zadaniem jest zachęcenie odbiorcy do skorzystania z konkretnych produktów lub usług. Sytuacja wygląda nieco inaczej w reklamie społecznej, której celem jest rozwiązanie lub przyczynienie się do rozwiązania określonego problemu. Reklama społeczna zazwyczaj stanowi kluczowy element kampanii społecznej. Kampanie społeczne organizowane są przez wiele podmiotów, mogą mieć zasięg lokalny, regionalny, krajowy lub mię- 
dzynarodowy. Często dotyczą cyklicznie pojawiających się w społeczeństwie zagadnień. Mimo dużego zainteresowania, ogromnej ważności poruszanych problemów pojawia się pytanie, czy reklamy społeczne mają nadal silny wpływ na odbiorców. Wzrastająca ilość oferowanych tego typu działań może wpłynąć na przyzwyczajenie lub zobojętnienie części odbiorców względem poruszanej problematyki. Jednak mimo to należy pamiętać, że wszelkie tego typu akcje są pozytywnym zjawiskiem i powinny być dalej realizowane, ponieważ mimo pojawiających się zakłóceń lub ograniczeń silnie oddziałują na dużą grupę odbiorców. Istotne jest, żeby przekaz był czytelny, trafiał do określonych grup społecznych lub całych społeczeństw oraz, uczulając na istotne problemy, powodował zmianę postaw i korektę negatywnych lub obojętnych zachowań.

\section{Literatura}

1. Budzyński W. (2007), Reklama. Techniki skutecznych perswazji, Poltext, Warszawa.

2. Gołaszewska-Kaczan U. (2009), Zaangażowanie społeczne przedsiębiorstwa, Wydawnictwo Uniwersytetu w Białymstoku, Białystok.

3. http://przerwanareklame.pl/ (dostęp: 28.12.2015).

4. http://www.kampaniespoleczne.pl (dostęp: 28.12.2015).

5. http://www.wwf.pl/ (dostęp: 28.12.2015).

6. Kaczmarczyk S., Pałgan R. (2005), Marketing w przedsiębiorstwie, ujęcie zarządcze i systemowe z przyktadami, ODDK, Gdańsk 2005.

7. Kotler P. (2005), Marketing, Dom Wydawniczy Rebis, Poznań.

8. Kozłowska A. (2012), Techniki perswazyjne oddziałujace na postawy konsumpcyjne, [w:] Kozłowska A. (red.), Strategie komunikacji reklamowej z konsumentem, Wyższa Szkoła Promocji, Warszawa.

9. Limański A., Drabik I. (2007), Marketing w organizacjach non-profit, Difin, Warszawa.

10. Maison D., Wasilewski P. (2002), Propaganda dobrych serc, czyli rzecz o reklamie społecznej, Agencja Wasilewski, Kraków-Warszawa.

11. Pabian A. (2008), Promocja. Nowoczesne środki i formy, Difin, Warszawa.

12. Prochenko P. (2010), Kampania społeczna - definicja Fundacji Komunikacji Społecznej, http://www.kampaniespoleczne.pl/wiedza_definicje,2324,kampania_spoleczna_definicja_fu ndacji_komunikacji_spolecznej (dostęp: 21.12.2015).

13. Skuteczny plan promocji, PARP, https://www.parp.gov.pl/files/74/517/20358.pdf (dostęp: 20.12.2015).

14. Sławińska M. (red.) (2008), Kompendium wiedzy o handlu, Wydawnictwo Naukowe PWN, Warszawa.

15. Tarczydło B. (2013), Kampania społeczna w teorii i praktyce, „Studia Ekonomiczne. Zeszyty Naukowe Uniwersytetu Ekonomicznego", nr 157: Wykorzystanie nowych mediów w public relations, Gołuchowski J., Frączkiewicz-Wronka A. (red.), Wydawnictwo Naukowe Uniwersytetu Ekonomicznego w Katowicach, Katowice.

16. Wiktor J.W. (2006), Promocja. System komunikacji przedsiębiorstwa z rynkiem, Wydawnictwo Naukowe PWN, Warszawa. 


\title{
ADVERTISING ACTIVITIES - FROM COMMERCIALISM TO SOCIAL CAMPAIGNS
}

\begin{abstract}
The aim of this article is presentation of social advertising and social campaign as an important elements of functioning of present communities. In this elaboration is also presented a comparison of commercial and social advertise ment. Both have a lot in common despite of different tasks. Both types of advertisements are complex process, which needs precise preparation. The recipients are an significant element of each campaign. This group is usually bigger than recipients of commercial. In the end of article are presented examples of social campaigns which were realized in Poland and all over the world. They concerned environment and animal rights.
\end{abstract}

Keywords: commercial, social advertising, social campaign 